\title{
Correlation between ESBL-Producing Bacteria Infection with Sepsis Severity of Patient in Medical Ward of Internal Medicine Department Dr. Soetomo General Hospital in 2016
}

\section{Asri Dhea Pratiwi ${ }^{1}$, Musofa Rusli ${ }^{\star}$, Budi Utomo ${ }^{3}$}

\author{
${ }^{1}$ Faculty of Medicine, Universitas Airlangga, Surabaya, Indonesia. \\ ${ }^{2}$ Department of Internal Medicine, Faculty of Medicine, Universitas Airlangga - Dr. Soetomo General Hospital, Surabaya, \\ Indonesia. \\ ${ }^{3}$ Department of Public Health and Preventive Medicine, Faculty of Medicine, Universitas Airlangga, Surabaya, Indonesia.
}

\begin{abstract}
A B S T R A C T
Introduction: Sepsis is life-threatening condition that begins with infections that trigger pro-inflammation over response. Delaying antibiotic treatment in sepsis can cause serious condition. In ESBL-producing bacteria, the antibiotic resistance is common and it might cause harm to sepsis patient. This research aims to analyze the correlation between infections of ESBL-producing bacteria with sepsis severity.
\end{abstract}

Methods: This study was observational analytic on sepsis patient in Internal Medicine Ward of Dr. Soetomo General Hospital. The data were taken from medical records of the patient. The severity of sepsis was based on Surviving Sepsis Campaign 2012.

Results: A total 72 sepsis patients were included in this study, which consist of 40 patients with non-producing ESBL GNB and 32 patients with ESBL-producing bacteria. The most common bacteria in ESBL infection is Escherichia coli ESBL+ (75\%) and non ESBL infection is Acinetobacter baumanii (27.5\%). Septic shock is more common in patient with ESBL-producing bacteria (53.1\% vs $22.5 \%)$. The correlation between ESBL infection and sepsis severity is significant and the power of correlation is low ( $p=0.048 ; r=0.234)$.

Conclusion: There is a correlation between ESBL-producing bacteria infection with sepsis severity and the power of correlation is low $(p=0.048, r=0.234)$.

\footnotetext{
* Correspondence: Musofa-r@fk.unair.ac.id

JUXTA: Jurnal IImiah Mahasiswa Kedokteran Universitas Airlangga p-ISSN: 1907-3623; e-ISSN: 2684-9453

DOI: 10.20473/juxta.V10I22019.84-86
}

Open access under Creative Commons Attribution-ShareAlike 4.0 International License (CC-BY-SA) C) (i) (2)
ARTICLE INFO

Article history:

Received 09 August 2019

Received in revised form 20

August 2019

Accepted 26 August 2019

\section{Keywords:}

Sepsis,

ESBL,

Gram negative bacteria,

Severe Sepsis,

Septic Shock. 


\section{Introduction}

Sepsis is a condition caused by immuneoverresponse due to infection. In sepsis, leukocyte is activated and pro-inflammatory response becomes overwhelmed. ${ }^{1}$

Blanco et al., (2008) $)^{2}$ stated that the most prevalent causative bacteria was gram negative bacteria (50\%) with Escherichia coli as the leading cause (37.2\%) followed by Pseudomonas aeruginosa (20.9\%) and Acinetobacter baumanii (10.9\%). A study by Peirovifar et al., $(2014)^{3}$ concluded that the most prevalent ESBLproducing bacteria that cause sepsis in neonates was Klebsiella pneumoniae. Other research stated that ESBLproducing enterobacteriaceae infection was more fatale compared to the non ESBL $(47.3 \%$ vs $22.4 \%)$, the treatment cost was also higher ( $215 € .95$ vs $115 €)$. About $40-60 \%$ of the treatment cost was spent on antibiotics ${ }^{4}$.

A study conducted by Lee et al., $(2017)^{5}$ showed that sepsis patient caused by ESBL-producing enterobacteriaceae happened more to fall into septic shock $(26.2 \%)$ compared with sepsis patient due to nonESBL producing (17.2\%). Peirovifar et al., (2014) $)^{3}$ also stated that 34 from 38 sepsis patient that die in Iran were caused by ESBL-producing bacteria. Blomberg et al., $(2005)^{6}$ also concluded that infections caused by ESBLproducing bacteria is more fatale compared to non ESBLproducing bacteria ( $71 \%$ vs $39 \%)$. The result of previous research indicates that the ESBL-producing bacteria infection caused more severe sepsis compared to the non ESBL bacteria.

Sepsis criteria has changed for several times since 1991. The 1991 SCCM/ACCP Consensus Conference divided sepsis into three groups, sepsis, severe sepsis, and septic shock ${ }^{7}$. Sepsis criteria was revised in 2001 SCCM/ESICM/ACCP/ATS/SIS International Sepsis Definitions Conference ${ }^{8}$ and revised again in Surviving Sepsis Campaign in 2012 but still divides sepsis into three groups ${ }^{9}$. The latest sepsis criteria was made in 2016 by The Third International Consensus Definition for Sepsis and Septic Shock (Sepsis-3) and divide sepsis severity into two groups, sepsis and septic shock ${ }^{10}$.

\section{Methods}

This study was observational analytic using crosssectional design. The purpose of this study was to analyze the correlation between ESBL-producing bacteria infection with sepsis severity, particularly in Dr. Soetomo General Hospital. This study also showed the distribution of gram negative bacteria that causes sepsis and also the severity of sepsis within each group.

The population of this study was all inpatient sepsis patients in Internal Medicine Ward of Dr. Soetomo General Hospital from 1 January 2016 to 31 December 2016. Criteria for inclusion in this study was sepsis patient, hospitalized in Internal Medicine Ward during 1 January 2016 to 31 Desember 2016, culture has shown gram negative non ESBL or ESBL-producing, and the medical record is complete. The sepsis criteria used in this study was based on Surviving Sepsis Campaign 2012 that put sepsis into 3 classes (sepsis, severe sepsis, and septic shock). This criteria was chosen since it differentiated sepsis into more specific classes compared to the latest sepsis criteria that only divided sepsis into septic and septic shock.

The data of this study were obtained from medical records of sepsis patient that match the inclusion criteria. Data were analyzed using SPSS 23. Statistical analysis of correlation between the bacteria and sepsis severity was done by rank spearman test.

This study can be used as a reference for the upcoming or other studies in other centre about sepsis and also increase the awareness of sepsis and proper use of antibiotics.

\section{Results}

This study enrolled 72 sepsis patients with culturepositive isolate indicating gram negative bacteria infection (40 patients) and ESBL-producing bacteria infection (32 patients). The most prevalent bacteria for the nonproducing ESBL gram negative bacteria was Acinetobacter baumanii (27.5\%), followed by Escherichia coli (20\%) and Klebsiella pneumoniae (17.5\%). The most common ESBLproducing bacteria was Escherichia coli ESBL+ (75\%), followed by Klebsiella pneumoniae ESBL+ (21.9\%) and Klebsiella oxytoca (3.1\%). The result is described in table 1.

Table 1. Distribution of bacteria from sepsis patient.

\begin{tabular}{lll}
\hline \multicolumn{1}{c}{ Bacteria } & $\begin{array}{l}\text { Frequency } \\
(\mathrm{n})\end{array}$ & $\begin{array}{l}\text { Percentage } \\
(\%)\end{array}$ \\
\hline Non-producing ESBL & & \\
GNB & & 27,5 \\
$\quad$ Acinetobacter baumanii & 11 & 20 \\
Escherichia coli & 8 & 17,5 \\
Klebsiella pneumonia & 7 & 5 \\
Burkholderiacepacia & 2 & 5 \\
Pseudomonas & 2 & \\
aeruginosa & & 2,5 \\
Citrobacter freundii & 1 & 2,5 \\
Empedobacter brevis & 1 & 2,5 \\
Enterobacter aerogenes & 1 & 2,5 \\
Enterobacter cloacae & 1 & 2,5 \\
Pantoea agglomerans & 1 & 2,5 \\
Proteus vulgaris & 1 & 2,5 \\
Providencia rettgeri & 1 & 2,5 \\
$\quad$ Providencia stuartii & 1 & 2,5 \\
Pseudomonas spp & 1 & 2,5 \\
Raoultella orthinolytica & 1 & 100 \\
Total & 40 & \\
ESBL-producing & & \\
bacteria & & \\
Escherichia coli ESBL + & 24 & 75 \\
Klebsiella pneumoniae & 7 & 21,9 \\
ESBL+ & & 3,1 \\
Klebsiella oxytoca & 1 & 100 \\
ESBL+ & & \\
Total & 32 & \\
\hline Source: research data, processed &
\end{tabular}


From 72 patients, we put the patient into 3 classes (sepsis, severe sepsis, and septic shock) based on Surviving Sepsis 2012 criteria. In non ESBL-producing gram negative bacteria group, the most common condition was severe sepsis $(52.5 \%)$ and in the ESBLproducing bacteria group, the most common condition was septic shock (53.1\%). The correlation between ESBL-producing bacteria infection with sepsis severity was analyzed using rank-spearman method. The $p$-value is 0.048 and the correlation coefficient is 0.234 . This result stated that there is a low correlation between ESBL-producing-bacteria infection with sepsis severity. The result is described in table 2 .

Table 2. Rank-spearman correlation test.

\begin{tabular}{|c|c|c|c|c|c|}
\hline \multirow[b]{2}{*}{ Group } & \multicolumn{3}{|c|}{ Sepsis Severity } & \multirow[t]{2}{*}{$r^{*}$} & \multirow[t]{2}{*}{$p^{* *}$} \\
\hline & Sepsis & $\begin{array}{l}\text { Severe } \\
\text { sepsis }\end{array}$ & $\begin{array}{l}\text { Septic } \\
\text { shock }\end{array}$ & & \\
\hline $\begin{array}{l}\text { Non- } \\
\text { producing } \\
\text { ESBL } \\
\text { GNB }\end{array}$ & $\begin{array}{c}10 \\
(25.0 \%)\end{array}$ & $\begin{array}{c}21 \\
(52.5 \%)\end{array}$ & $\begin{array}{c}9 \\
(22.5 \%)\end{array}$ & 0.234 & 0.048 \\
\hline $\begin{array}{l}\text { ESBL- } \\
\text { producing } \\
\text { bacteria }\end{array}$ & $\begin{array}{c}7 \\
(21.9 \%)\end{array}$ & $8(25 \%)$ & $\begin{array}{c}17 \\
(53.1 \%)\end{array}$ & & \\
\hline Total & $\begin{array}{c}17 \\
(23.6 \%)\end{array}$ & $\begin{array}{c}29 \\
(40.3 \%)\end{array}$ & $\begin{array}{c}26 \\
(36.1 \%)\end{array}$ & & \\
\hline
\end{tabular}

Source: research data, processed

* correlation coefficient

* correlation between groups, significant in $<0.05$

\section{Discussion}

\section{Distribution of bacteria in sepsis patient}

The most prevalent bacteria for the non-producing ESBL gram negative bacteria was Acinetobacter baumanii (27.5\%), followed by Escherichia coli (20\%) and Klebsiella pneumoniae (17.5\%). The result of this study is different from several studies. Blanco, et al. ${ }^{2}$ stated that Eschericia coli is the most common gram negative bacteria that caused sepsis and Acinetobacter baumanii was at the fourth position. Lochan et al., ${ }^{11}$ also stated that Acinetobacter is the third most common gram-negative bacteria that cause sepsis, below Escherichia coli and Klebsiella pneumoniae. This result can be different from two studies above because those two studies did not differ between ESBL and non ESBL-producing gram negative bacteria. In the other hand, Khanna et al., showed that $46.2 \%$ of Eschericia coli and $55.5 \%$ of Klebsiella pneumoniae in hospitalized patient are found to be ESBL $+{ }^{12}$.

Acinetobacter baumanii is an anaerobic-gramnegative-bacteria that is likely to cause nosocomial and opportunistic infections. This bacteria is also stated as one of the leading cause of sepsis and cause a high mortality rate in ICU patients ${ }^{13}$. Acinetobacter baumanii is quite alarming since they are likely to be resistant to many antibiotics. The high infection number of Acinetobacter baumanii in this study could also indicate that nosocomial infection was also high and it could be dangerous.

In ESBL-producing bacteria group is Escherichia coli $E S B L+(75 \%)$. The result of this study is almost the same with the study conducted by Shaikh et al., ${ }^{14}$ and Sakellariou et al., ${ }^{15}$ that also reported that the most prevalent ESBL-producing bacteria was also Escherichia coli $E S B L+$. Different results came from Kuntaman et al., ${ }^{15}$ and Dewan et al., ${ }^{16}$ which showed that Klebsiella pneumoniae ESBL+ is the most common bacteria that is isolated from the patients.

\section{Correlation between ESBL-producing bacteria infection and sepsis severity}

This research concluded that there is a significant correlation ( $p$-value 0.048) between ESBL-producing bacteria infection and severity and the power of correlation is low (correlation coefficient 0.234 ). This result is quite similar with other studies. A study conducted by Lee et al., $(2017)^{5}$ showed that sepsis patient caused by ESBLproducing enterobacteriaceae happened more to fall into septic shock (26.2\%) compared with sepsis patient due to non - ESBL producing enterobacteriaceae (17.2\%). Peirovifar et al., $(2014)^{3}$ also stated that 34 from 38 sepsis patient that die in Iran were caused by ESBL-producing bacteria. Blomberg et al., $(2005)^{6}$ also stated that infections caused by ESBL-producing bacteria is way more fatale than infection caused by non ESBL-producing bacteria $(71 \%$ vs $39 \%)$. The result of previous research indicated that the ESBL-producing bacteria infection caused more severe sepsis compared to the non ESBL bacteria. The result of this study also matched the theory that stated the resistance to antibiotics can raise the risk of sepsis patient to fall into worse condition such as septic shock or even death. ${ }^{9}$

\section{Conclusion}

There is a correlation between ESBL-producing bacteria infection with sepsis severity and the power of correlation is low $(p=0.048, r=0.234)$.

\section{CONFLICT OF INTEREST}

The author stated there is no conflict of interest in this study.

\section{REFERENCES}

1.Vincent J-L, Zhang H, Szabo C and Preiser J-C. Effects of Nitric Oxide in Septic Shock. American Journal of Respiratory and Critical Care Medicine. 2000; 161: 1781-5.

2.Blanco J, Muriel-Bombin A, Sagredo V, et al. Incidence, Organ Dysfunction and Mortality in Severe Sepsis: A Spanish Multicentre Study. Critical Care (London, England). 2008; 12: R158.

3.Peirovifar A, Rezaee Ma and Gharehbaghi Mm. Prevalence of Multidrug Resistant Extended-Spectrum Beta-Lactamase 
Producing Gram-Negative Bacteria in Neonatal Sepsis. International Journal of Women's Health and Reproduction Sciences. 2014; 2: 138-45.

4.Ndir A, Diop A, Ka R, et al. Infections Caused by Extended-Spectrum Beta-Lactamases Producing Enterobacteriaceae: Clinical and Economic Impact in Patients Hospitalized in 2 Teaching Hospitals in Dakar, Senegal. Antimicrob Resist Infect Control. 2016; 5: 13-.

5.Lee $\mathrm{CH}$, Chu FY, Hsieh CC, et al. A Simple Scoring Algorithm Predicting Extended-Spectrum BetaLactamase Producers in Adults with Community-Onset Monomicrobial Enterobacteriaceae Bacteremia: Matters of Frequent Emergency Department Users. Medicine. 2017; 96: E6648.

6.Blomberg B, Jureen R, Manji KP, et al. High Rate of Fatal Cases of Pediatric Septicemia Caused by Gram-Negative Bacteria with Extended-Spectrum Beta-Lactamases in Dar Es Salaam, Tanzania. Journal of Clinical Microbiology. 2005; 43: 745-9.

7.Bone RC, Sibbald WJ and Sprung CL. The ACCP-SCCM Consensus Conference on Sepsis and Organ Failure. Chest. 1992; 101: 1481-3.

8.Levy MM, Fink MP, Marshall JC, et al. 2001 SCCM/ESICM/ACCP/ATS/SIS International Sepsis Definitions Conference. Critical Care Medicine. 2003; 31: 1250-6.

9.Rhodes A, Evans LE, Alhazzani W, et al. Surviving Sepsis Campaign: International Guidelines for Management of Sepsis and Septic Shock: 2016. Critical Care Medicine. 2017; 45: 486-552.

10.Singer M, Deutschman CS, Seymour CW, et al. The Third International Consensus Definitions for Sepsis and Septic Shock (Sepsis-3) Consensus Definitions for Sepsis and Septic Shockconsensus Definitions for Sepsis and Septic Shock. JAMA. 2016; 315: 801-10.

11.Lochan $\mathrm{H}$, Pillay V, Bamford $\mathrm{C}$, Nuttall $\mathrm{J}$ and Eley $\mathrm{B}$. Bloodstream Infections at a Tertiary Level Paediatric Hospital in South Africa. BMC Infectious Diseases. 2017; 17: 750.

12.Khanna A, Khanna M and Gill M. ESBL Producing Gram Negative Bacteria-A Cause of Concern in Neonatal Septicemia in a Tertiary Care Hospital. International Journal of Current Microbiology And Applied Sciences. 2016; 5: 807-13.

13.Wei HM, Hsu YL, Lin HC, et al. Multidrug-Resistant Acinetobacter Baumannii Infection among Neonates in a Neonatal Intensive Care Unit at a Medical Center in Central Taiwan. Journal of Microbiology, Immunology, and Infection = Wei Mian Yu Gan Ran Za Zhi. 2015; 48: 531-9.

14.Shaikh S, Fatima J, Shakil S, Rizvi SM and Kamal MA. Antibiotic Resistance and Extended Spectrum BetaLactamases: Types, Epidemiology and Treatment. Saudi Journal of Biological Sciences. 2015; 22: 90-101.

15.Sakellariou C, Gurntke S, Steinmetz I, et al. Sepsis Caused by Extended-Spectrum Beta-Lactamase (ESBL)Positive K. Pneumoniae and E. Coli: Comparison of Severity of Sepsis, Delay of Anti-Infective Therapy and ESBL Genotype. Plos One. 2016; 11: E0158039.

16.Kuntaman K, Santoso S, Wahjono $H$, et al. The Sensitivity Pattern of Extended Spectrum Beta Lactamase-Producing Bacteria Against Six Antibiotics that Routinely Used in Clinical Setting. Madjalah Kedokteran Indonesia. 2011; Vol. 61: 482-6. 